\title{
西井凉子 著
}

\section{『情動のエスノグラフィ 一南夕イの村で感じる・つながる・生きる』}

京都大学学術出版会 2013年 vii +286頁

\section{鈴木 佑記}

本書は, 調査村における「生と死」をめぐる出来事を, 著者の感性と経験にもとづ いて記述した民族誌（エスノグラフィ）である。著者が，本書の舞台となる南夕イの 村落でフィールドワークを開始したのは 1987 年であり, 調査地の人々との関係はすで に20年以上におよぶ。

本書を貫くキーワードは, タイトルにも使われている「情動」である。情動とは, 「意識や主体を越えて，共在する身体が互いに触発しあうことで，新たな活動の力を 生み出していくエネルギーのようなもの」（13頁）だという。つまり，単なる個人の 感情にもとづくパワーではなく，自己と他者（ときにマテリアリティ）の相互作用の 上に成り立つものであることを強調している。そうして生み出された「エネルギーの ようなもの」は，さらに他の人やモノなどと反響し合い，出来事を生み出してゆく。

著者は，調査村で発生した出来事のプロセスを微視的に描いている。具体的には， 集団憑依 (第 2 章), エビ養殖 (第 3 章), 姦通殺人 (第 4 章), 老女の死 (第 5 章), 病死 (第 6 章)，老女と著者と家 (第 7 章) に関する 6 つの出来事が扱われている。 以下，第 1 章で紹介されている村落の概況を説明した上で，章ごとに概要をまとめる。

調査村は，マレーシアと国境を接する夕イ最南端のサトウーン県に位置する。サト ウーン県は, 仏教徒が人口の 9 割以上を占める夕イにおいて, 半数がムスリムという イスラームが浸透した県である。この県では, 仏教徒とムスリムの間での通婚がみら れ，宗教面での特徵として，通婚にともなう双方向の，つまりムスリムから仏教徒へ， あるいは仏教徒からムスリムへの改宗がみられる（詳しくは，西井 [2001］を参照)。

第 2 章「集団憑依 : 伝染する情動」では, 調査村の中学 1 年から高校 3 年までの 子どもが通う学校で次々と発生した憑依騒動について検討している。この学校では, 2004年12月から2005年 2 月までの約 3 力月間に, 138回の憑依現象が起きた。著者は, その学校の教員と生徒へのインタビューにもとづいて，憑依の経過や様態を説明して 
いる。精霊が生徒に憑依する現象が頻繁にみられるようになり，身体から身体へと憑 依が伝染していくなかで，教員や生徒，それに村人や呪医や役人なども巻き込まれて いく様子が伝えられる。ここでは，精霊と精霊に憑依された身体，あるいは生徒の身 体どうしが共鳴し合い，情動の力が他者へ作用していく流れが緻密に描かれ，整理さ れている。

第 3 章「クルー・ノーム:『のめり込む』生」では，エビ養殖に関わつた人々のラ イフヒストリーから, 生の偶然性と能動性について考察している。タイでは1980年代 以降，エビ養殖が盛んに行われるようになっており，調査村でも1990年代から多くの 人が事業に参加するようになった。しかしながら，ほとんどの人が莫大な損失を出し て，エビ養殖から手を引いている。ビジネスというより「賭け事」としてエビ養殖が 村人に経験されている点を明らかにしたうえで, 事業から抜け出すことが困難な状況 に陥った人々の経験を追うことで，個の生の偶然性と，その偶然性を受容しながらも よりよい生活を求めようとする生の能動性について論じている。

第 4 章「チャイ: 『濰通殺人事件』」では，マングローブ林に囲まれた調査村で起き た殺人事件を取り上げている。章題にもなっているチャイとは，姦通行為をした男性 の名前であり，相手の女性の夫に殺されてしまった人物である。姦通行為をされた女 性の夫は「ピーノーン（兄弟，あるいは身近な人の意）」とは真逆の「外の人」であ るために，村人からは仲間がいない人とみなされる一方で，何をしでかすかわからな い怖い存在でもある。その彼がチャイを殺害したことで，「外の人」としてのイメー ジがさらに強化されたと考えられるわけだが，「サックシー(威厳や尊厳の意)」の観 点からは，姦通した相手（チャイ）を殺すのは仕方のないこととして村人たちから同 情的に受け止められている。村という共住空間において重層的に行為が作用していく 様を，「姦通殺人事件」という出来事を通して描いている。

第 5 章「ヤーイ・チット：老女は自殺したのか」では，ヤーイ・チットという老女 の死をめぐる, 村人の解釈を丹念に追つている。老女が死体でみつかった場所は, 彼 女の家の裏である。そこは川ではあるが，干潮時には干上がるところであり，過去に 子どもが首つり自殺をした場所でもある。そうした場所の特性や過去の出来事だけで なく, 老女の親子関係やかつての言動から，村人の多くが今回の出来事を自殺と判断 している様子を著者は細やかに描いている。他方，老人によくみられる徘徊の結果の 事故と捉える人がいるなど，個の存在のあり方が他者に様々なかたちで受容されてい ることも明らかにしている。最後には，自殺したと思っている人も，そうでないと思

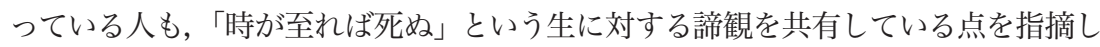
ている。

第 6 章「ノン: 死のにおい」では，病気によって死んだ青年ノンを取り上げ，彼の 
死をめぐる出来事を分析している。遺体の搬送中に何百頭もの犬に出合うという不思 議な出来事に遭遇した後，搬送車内にカイ・パロ（煮卵の汁料理）のにおいが充満し， 死者であるノンがおならをしたと家族が話すエピソード，ゴム園で働いている最中に 突如においを感じてノンが訪ねてきたと解釈する兄弟のエピソードなどが紹介され， 死がにおいとして受動的に経験される状況を説明している。また，家族の都合により 他村で葬式を挙げたことが，調査村で遺体の不在として問題になった事件や，エイズ 治療のために薬を服用したノンが，アレルギー反応が出たにもかかわらず生きるため に薬を飲み続けたことが死因となった事実に触れることで, 著者は生と死の偶有性を 描き出している。

第 7 章「ナー・チュア：人と家と『私＝民族誌家』では，ナー・チュアという 1 人の老女と，彼女の家にかかわる人々をめぐる物語を検討している。ナー・チュアの ライフヒストリーをたどり, 彼女の家に同居した重要人物の経歴紹介を通して, 家と 人の結びつきが，人間の生にとって大事なものであることを示している。また，ナ ー・チュアが書きとめた「功徳の転送リスト（彼女が積んできた功徳を誰に送るかを 示したもの)」と「援助記録（他人からもらった金額を記したもの）」に，彼女の家 に密接に関連する人物の名前が載せられている点を指摘したうえで，人間の生と死が， 著者をも巻き込みながら, 家と密接につながうていることを著者は説得的に論じてい る。

以上が，本書の概要である。本書の意義は，まず，四半世紀の人間関係にもとづい て得られた詳細なデータが提示されている点にある。人類学者同士の会話において, 博士号の取得や単著の出版を契機に新たなフィールドを開拓するなかで，それまでお 世話になった調査村の人々との関係性が希薄化していつたという話を聞くことがある。 ところが著者は，一つのフィールドにこだわり，ほぼ毎年南夕イの調査村に足を運び， 真摰に村人たちと向き合いながらフィールド調査を続けてきた。本書は，そうした調 査にもとづく, 他の人類学者では決して得られない資料が随所に散りばめられた重厚 な民族誌に仕上がっている。

また，南夕イで発生した「〈普通の〉出来事」を紹介している点も高く評価される べきであろう。一般に, マレーシアとの国境近い夕イ南部と聞くと, テロ活動が活発 な地域を想起する人が多く, 夕イ研究者も「事件」と名のつく事象にばかり目を向け がちである。憑依現象を〈普通〉とは呼べないかもしれないが，それでも評者は，こ れまでに夕イ南部で多くの憑依現象が起きている事実 (69-71頁) を本書で初めて知 った。タイの他地域に比べて圧倒的に研究成果がそしい南夕イの, 〈普通〉の人々の 生活を取り上げたことは，夕イ地域研究にとって大きな意味を持っている。

このように，人類学や地域研究への貢献がなされている本書だが，評者が何よりも 
評価したいのは，調査者の責務を追求し，暫定的ではあるが一つの答えを示した点に ある。著者は長期間の現地との関わりを通じて，「自分は何のために人類学的調査を 行っているのか」彼らと生を共にすることで書くエスノグラフィの目的は何であるの か」という疑問をずっと持ち続けていたという（3 頁)。これらの問いには，フィー ルドワーカーなら誰もが持っている，調査地の人々に対する負い目や責務が含まれて いる。このシンプルだが非常に重要な問いに対して，著者は次のように明確に答える。 「エスノグラフィを書くにあたつて私のやるべきことは，私自身が，私の身体が，共鳴 体となり，出来事を感受し，それを人に伝えるように記述することである」（5頁）と。 南夕イの人々と深く関わるようになった偶然性，またそこで起きた多くの出来事にい やおうなく巻き込まれた受動性，そしてそれらの事実を必然なものとして受け入れて， 出来る限り詳細に記述して他者へ伝えること，それが20年以上かけて導き出した著者 の答えである。このように，調査者の責務に対する著者の考えが明示されている点が， 本書の学術的価値を一層高めている。

他方で，評者は，この著者の答えに若干の違和感を抱いてもいる。なぜなら結局は， 調査の成果を発信する以外に，調査者の責務は果たせないという，ごく当たり前のこ とを述べているにすぎないと思えるからだ。調査地で発生する出来事を可能な限り記 録に残し，それらの情報を，読み手や聞き手に伝わるように表現を工夫するというの は，これまでも人類学者や地域研究者が行ってきたことではないだろうか。おそらく， 人に伝える際に重要なものとして, 著者は「情動」に答えを見出したと思う。しかし, その情動が具体的にどのように作用するものなのか，本書を読み終えても評者は完全 には理解できなかった。とはいえ，その一点のみを指摘したところで，本書の成果と 価値が摇らぐことはない。本書がフィールドワーカーにひろく読まれ，著者の情動が より多くの人に伝染することを願つている。また，30年，40年と村人とつながった後 に書かれる著者の作品を，今から楽しみにしている。

\section{参考文献}

西井凉子．2001。 『死をめぐる実践宗教：南夕イのムスリム・仏教徒関係へのパースペクテ イブ』世界思想社。 